\title{
The effects of dietary medium-chain triacylglycerols on growth performance and intestinal microflora in young pigs
}

\author{
W.K. Lai ${ }^{1}$, H.C. Yen ${ }^{1}$, C.S. Lin ${ }^{2}$ and S.H. Chiang ${ }^{1,3}$ \\ ${ }^{1}$ Tunghai University, Department of Animal Science and Biotechnology, Taichung 407, Taiwan \\ ${ }^{2}$ Agricultural Research Institute, Division of Applied Biology, Animal Technology Laboratories, Miaoli 350, Taiwan
}

KEY WORDS: growth performance, intestinal microflora, medium-chain triacylglycerols, pigs

Received: 14 February 2014

Revised: 25 September 2014

Accepted: 28 November 2014

${ }^{3}$ Corresponding author:

e-mail: shchiang@thu.edu.tw

\begin{abstract}
Ninety-six young pigs were used to investigate the effect of dietary supplementation with medium-chain triacylglycerols (MCT) on growth performance and intestinal microbial counts. The pigs were divided into four treatments, with four replicates per treatment. Six pigs were assigned per replicate and were fed diets supplemented with 1. 6.0\% soyabean oil (SO), 2. $4.8 \%$ SO + 1.2\% MCT, 3. $3.0 \%$ SO $+3.0 \%$ MCT, or $4.1 .2 \%$ SO $+4.8 \%$ MCT for 28 days. The results showed that dietary supplementation with $4.8 \%$ MCT improved the gain-to-feed ratio of the pigs $(P<0.05)$. Dietary supplementation with $3.0 \%$ MCT decreased the lactic acid bacteria $(L)$ counts in the stomach and caecum, while supplementation with $4.8 \%$ MCT decreased the $L$ counts in the stomach and the small intestine $(P<0.05)$. Dietary supplementation with MCT increased the L-to-coliforms $(C)$ ratio in the colon and rectum $(P<0.01)$ and decreased $\mathrm{L}+\mathrm{C}$ in the stomach $(P<0.05)$. In conclusion, dietary supplementation with $4.8 \%$ MCT may change the intestinal microbiota and improve the feed utilization efficiency of young pigs.
\end{abstract}

\section{Introduction}

Medium-chain triacylglycerols (MCT) have fatty acids that are 6-12 carbon atoms long and can be easily utilized as an energy source by humans (Bach and Babayan, 1982), pigs (Chiang et al., 1990b) and chickens (Chiang et al., 1990a; Furuse et al., 1992).

During the late 1970 s and the early 1980 s, researchers found that a high dietary level of MCT (i.e. $10 \%-35 \%$ ) either does not affect, or negatively affects the growth performance of young pigs (Allee et al., 1972; Newport et al., 1979) and rats (Lavau and Hashim, 1978; Travis et al., 1979; Baba et al., 1982). Recently, however, researchers have found that a low dietary level of MCT (i.e. $0.2 \%-5 \%$ ) could improve the growth performance of weanling pigs (Dierick et al., 2002b; Hanczakowska et al., 2011; Hong et al., 2012) and broilers (Chiang et al., 1990a).

The bactericidal effect of medium-chain fatty acids (MCFA) has been documented for decades (Nieman, 1954). Recently, however, it was found that dietary MCFA could inhibit Lactobacillus, Streptococcus and Escherichia coli in the stomach and small intestine (Dierick et al., 2002a,b) and Clostridium perfringer in the small intestine (Hanczakowska et al., 2011) of weanling pigs. The bactericidal effect of antibiotics is one of the reasons for their growthpromoting effects in animals. Nevertheless, due to the cross-resistance issue of antibiotics, the European Union and other countries have completely or partially banned their use for disease prevention purposes. The bactericidal and cross-resistance-free 
properties of MCT make them a good alternative to antibiotics.

The purpose of the present study was to investigate the effect of dietary supplementation with lower levels of MCT on the growth performance of young pigs and their intestinal microbial counts.

\section{Material and methods}

All animal-related protocols in the study followed the Guide for the Care and Use of Laboratory Animals (NRC, 1996). Ninety-six crossbred young pigs [Duroc $\times$ Landrace $\times$ Yorkshire; $17.4 \pm 3.0 \mathrm{~kg}$ of body weight $(\mathrm{BW})$ ] were assigned by $\mathrm{BW}$ and sex to four treatments, with four replicates per treatment and six pigs ( 3 barrows and 3 gilts) per replicate. Each pen was $2.5 \times 2.5 \mathrm{~m}$ in size with a concrete floor, two nipple waterers, and a four-hole self-feeder.

Pigs were fed diets based on maize, soyabean meal and whey powder supplemented with $1.6 .0 \%$ soyabean oil (SO), 2. $4.8 \% \mathrm{SO}+1.2 \%$ of mediumchain triacylglycerols (MCT), 3. 3.0\% SO $+3.0 \%$ MCT and 4. $1.2 \% \mathrm{SO}+4.8 \% \mathrm{MCT}$ for 28 days (Table 1). The fatty acid compositions of SO (Fusow Company, Taichung, Taiwan) and MCT (Yihai Kerry Group, Shanghai, China) are shown in Table 2. Dietary nutrients were provided to meet or exceed requirements for weanling pigs (NRC, 1998). Feed and water were fed ad libitum. Feed was provided in meal form.

Pigs were weighed individually and feed intake was measured on a pen basis weekly. The weight gain, feed intake and gain-to-feed ratio $(\mathrm{G}: \mathrm{F})$ were calculated weekly on a pen basis. Chromic oxide $(0.25 \%)$ was added in the diets as the digestibility marker during the last week of the trial. Fresh faeces were collected for 3 days followed by 3 days after the marker was added. Faeces were frozen at $-30^{\circ} \mathrm{C}$ for until analysis.

At the end of the trial, two pigs ( 1 barrow and 1 gilt) with a BW nearest to the replicate average were selected from each replicate and electrically stunned; all of the contents in the stomach, small intestine (including the duodenum, jejunum and ileum), caecum and colon and rectum were collected; and lactic acid bacteria (L) and coliforms (C) were counted immediately. Briefly, intestinal contents were homogenized and aliquots were taken and diluted with phosphatebuffered saline (Amresco, Solo, OH, USA). They were then incubated aerobically on MRS agar (Becton, Dickinson and Company, MD, USA) or Coliform agar (Merck KGaA, Damstadt, Germany) at $37^{\circ} \mathrm{C}$ for 48 or $24 \mathrm{~h}$, and the colonies of $\mathrm{L}$ and $\mathrm{C}$ were counted.
Table 1. Composition of experimental diets, as fed basis

\begin{tabular}{|c|c|c|c|c|}
\hline \multirow[b]{2}{*}{ Indices } & \multicolumn{4}{|c|}{ Treatment } \\
\hline & $\begin{array}{l}6.0 \% \\
\text { soya oil }\end{array}$ & $\begin{array}{c}4.8 \% \\
\text { soya oil + } \\
1.2 \% \mathrm{MCT}^{1}\end{array}$ & $\begin{array}{c}3.0 \% \\
\text { soya oil + } \\
3.0 \% \text { MCT }\end{array}$ & $\begin{array}{c}1.2 \% \\
\text { soya oil + } \\
4.8 \% \text { MCT }\end{array}$ \\
\hline \multicolumn{5}{|l|}{ Ingredient, \% } \\
\hline yellow maize & 45.59 & 45.59 & 45.59 & 45.59 \\
\hline $\begin{array}{c}\text { soyabean meal } \\
(47.5 \% \mathrm{CP})\end{array}$ & 24.33 & 24.33 & 24.33 & 24.33 \\
\hline fish meal $(63.3 \% \mathrm{CP})$ & 5.00 & 5.00 & 5.00 & 5.00 \\
\hline wheat middling & 6.00 & 6.00 & 6.00 & 6.00 \\
\hline whey protein & 12.00 & 12.00 & 12.00 & 12.00 \\
\hline sodium chloride & 0.25 & 0.25 & 0.25 & 0.25 \\
\hline dicalcium phosphate & 0.30 & 0.30 & 0.30 & 0.30 \\
\hline limestone & 0.08 & 0.08 & 0.08 & 0.08 \\
\hline Premix ${ }^{2}$ & 0.20 & 0.20 & 0.20 & 0.20 \\
\hline $\mathrm{Cr}_{2} \mathrm{O}_{3}$ & 0.25 & 0.25 & 0.25 & 0.25 \\
\hline soyabean oil & 6.0 & 4.8 & 3.0 & 1.2 \\
\hline MCT & 0.0 & 1.2 & 3.0 & 4.8 \\
\hline total & 100.00 & 100.00 & 100.00 & 100.00 \\
\hline \multicolumn{5}{|l|}{ Calculated values } \\
\hline $\mathrm{ME}, \mathrm{MJ} \cdot \mathrm{kg}^{-1,3}$ & 15.03 & 15.00 & 14.96 & 14.92 \\
\hline crude protein, $\%$ & 20.92 & 20.92 & 20.92 & 20.92 \\
\hline lysine, $\%$ & 1.27 & 1.27 & 1.27 & 1.27 \\
\hline crude fat, $\%$ & 9.11 & 9.11 & 9.11 & 9.11 \\
\hline $\mathrm{Ca}, \%$ & 0.78 & 0.78 & 0.78 & 0.78 \\
\hline total P, \% & 0.66 & 0.66 & 0.66 & 0.66 \\
\hline \multicolumn{5}{|l|}{ Analysed values, \% } \\
\hline crude protein, $\%$ & 20.01 & 20.71 & 20.15 & 20.34 \\
\hline total fatty acids, $\%$ & 8.24 & 8.32 & 8.22 & 8.35 \\
\hline C6:0 & 0.00 & 0.44 & 0.81 & 1.10 \\
\hline $\mathrm{C} 8: 0$ & 0.00 & 0.60 & 1.24 & 1.77 \\
\hline C10:0 & 0.00 & 0.34 & 0.78 & 1.14 \\
\hline C14:0 & 0.56 & 0.57 & 0.61 & 0.61 \\
\hline C16:0 & 1.34 & 1.62 & 1.31 & 0.87 \\
\hline C18:0 & 0.48 & 0.60 & 0.49 & 0.33 \\
\hline C18:1 & 2.04 & 2.01 & 1.51 & 1.00 \\
\hline C18:2 & 3.51 & 1.99 & 1.37 & 1.44 \\
\hline $\mathrm{C} 18: 3$ & 0.31 & 0.15 & 0.10 & \\
\hline
\end{tabular}

${ }^{1} \mathrm{MCT}$ - medium-chain triacylglycerols; ${ }^{2}$ provided per $\mathrm{kg}$ of diet: IU: vit. $A 12,000$, vit. $D_{3} 2,000$, vit. $E 40$; mg: vit. $K_{3} 4$, vit. $B_{1} 1.5$, vit. $B_{2} 1.5$, vit. $B$, vit. $B$, 0.05 , niacin 15 , pantothenic acid 16 , folic acid 1 , biotin 0.2 ,


bean oil used for the calculation were 32.92 (Lee and Chiang, 1994) and $35.15 \mathrm{MJ} \cdot \mathrm{kg}^{-1}$ (NRC, 1998), respectively

Table 2. Fatty acid composition of experimental oil

\begin{tabular}{ccc}
\hline Fatty acid, $\%$ & Soya oil & MCT $^{1}$ \\
\hline C6:0 & - & 24.9 \\
C8:0 & & 47.6 \\
C10:0 & - & 26.8 \\
C14:0 & - & - \\
C16:0 & 14.9 & - \\
C18:0 & 4.5 & 0.4 \\
C18:1 & 25.0 & 0.3 \\
C18:2 & 52.4 & - \\
C18:3 & 3.2 & - \\
\hline
\end{tabular}

${ }^{1} \mathrm{MCT}$ - medium-chain triacylglycerols 
Table 3. Effects of dietary $\mathrm{MCT}^{1}$ on growth performances of young pigs

\begin{tabular}{|c|c|c|c|c|c|c|}
\hline \multirow[b]{2}{*}{ Indices } & \multicolumn{4}{|c|}{ Treatment } & \multirow[b]{2}{*}{ SEM } & \multirow[b]{2}{*}{$P$} \\
\hline & $\begin{array}{l}6.0 \% \\
\text { soya oil }\end{array}$ & $\begin{array}{l}4.8 \% \\
\text { soya oil + } \\
1.2 \% \text { MCT }\end{array}$ & $\begin{array}{l}3.0 \% \\
\text { soya oil + } \\
3.0 \% \text { MCT } \\
\end{array}$ & $\begin{array}{l}1.2 \% \\
\text { soya oil + } \\
4.8 \% \text { MCT } \\
\end{array}$ & & \\
\hline \multicolumn{7}{|c|}{ Initial body weight } \\
\hline $\mathrm{kg}$ & 17.35 & 17.36 & 17.41 & 17.36 & 0.03 & 0.62 \\
\hline $\mathrm{CV}^{2}, \%$ & 16.52 & 16.37 & 18.03 & 17.64 & 1.49 & 0.82 \\
\hline \multicolumn{7}{|c|}{ Final body weight } \\
\hline $\mathrm{kg}$ & 32.55 & 32.63 & 32.78 & 32.86 & 0.45 & 0.98 \\
\hline $\mathrm{CV}^{2}, \%$ & 17.08 & 19.06 & 21.17 & 20.82 & 2.26 & 0.58 \\
\hline \multicolumn{7}{|c|}{$\begin{array}{l}\text { Weight gain, g } \text { day }^{-1} \\
\text { week }\end{array}$} \\
\hline 1 & 343 & 355 & 362 & 368 & 20.4 & 0.92 \\
\hline 2 & 521 & 459 & 530 & 495 & 15.6 & 0.14 \\
\hline 3 & 611 & 548 & 616 & 675 & 38.0 & 0.35 \\
\hline 4 & 691 & 822 & 698 & 679 & 69.5 & 0.61 \\
\hline overall & 543 & 545 & 549 & 554 & 13.3 & 0.96 \\
\hline \multicolumn{7}{|c|}{$\begin{array}{l}\text { Feed intake, } g \cdot \text { day }^{-1} \\
\text { week }\end{array}$} \\
\hline 1 & 672 & 680 & 717 & 714 & 20.9 & 0.55 \\
\hline 2 & 949 & 914 & 997 & 868 & 24.9 & 0.10 \\
\hline 3 & 1094 & 1088 & 1027 & 1060 & 35.5 & 0.70 \\
\hline 4 & 1512 & 1658 & 1465 & 1434 & 53.6 & 0.17 \\
\hline overall & 1056 & 1085 & 1051 & 1019 & 22.1 & 0.26 \\
\hline
\end{tabular}

Gain : feed ratio

week

\begin{tabular}{lllllll}
1 & 0.511 & 0.523 & 0.505 & 0.515 & 0.027 & 0.98 \\
2 & 0.548 & 0.502 & 0.533 & 0.570 & 0.017 & 0.23 \\
3 & 0.559 & 0.505 & 0.601 & 0.636 & 0.038 & 0.30 \\
4 & 0.457 & 0.492 & 0.478 & 0.473 & 0.038 & 0.97 \\
overall & $0.513^{\mathrm{a}}$ & $0.503^{\mathrm{a}}$ & $0.522^{\mathrm{ab}}$ & $0.543^{\mathrm{b}}$ & 0.006 & 0.05 \\
\hline
\end{tabular}

${ }^{1} \mathrm{MCT}$ - medium-chain triacylglycerols; ${ }^{2} \mathrm{CV}$ - coefficient of variation; a,bleast-squares means within a row lacking a common superscript letter differ at $P<0.05$

Samples of feed and freeze-dried faeces were ground. Crude protein contents were measured by the Kjeldahl method (AOAC, 1984). Fatty acids were transmethylated according to Sukhija and Palmquist (1988), and their contents were quantified using gas chromatography with a flame ionization detector (Hitachi G-3000, Tokyo, Japan) and a $30 \mathrm{~m} 0.25 \mathrm{~mm}$ Rtx-2330 fused silica capillary column (Restek Inc., Bellefonte, PA, USA) with C15:0 as the internal standard. Chromium contents were measured by the method of Williams et al. (1962) using atomic absorption spectrophotometry (Hitachi 170-30, Tokyo, Japan).

The apparent digestibility (AD) of fatty acids and crude protein was calculated by the following equation:

$\mathrm{AD}$ of fatty acid or crude protein $=$

$$
100-100 \times \frac{\begin{array}{l}
\text { chromium } \% \text { in diet } \times \text { fatty acid } \\
\text { or crude protein in faeces }
\end{array}}{\begin{array}{l}
\text { chromium } \% \text { in faeces } \times \text { fatty acid } \\
\text { or crude protein in diet }
\end{array}}
$$

Data were analysed using the GLM procedures of SAS (2003). The differences between each treatment were detected by the probability values generated by the least significant difference test. Differences were considered significant at $P<0.05$.

\section{Results}

Dietary supplementation with MCT did not affect the weekly weight gain, feed intake, or G:F (Table 3). However, dietary supplementation with $4.8 \%$ MCT increased the overall (weeks 1-4) G:F of pigs by $6 \%(P<0.05 ; 0.543$ vs 0.513$)$. Dietary supplementation with MCT had no effect on the uniformity (coefficient of variation, \%) of the final body weight of pigs (Table 3 ).

Dietary supplementation with $1.2 \%$ MCT increased $\mathrm{L}$ in the small intestinal content $(P<0.05$; Table 4). However, a further increase in the MCT level to $3.0 \%$ decreased $\mathrm{L}$ in stomach and caecal contents $(P<0.05)$. Dietary supplementation with $4.8 \%$ MCT decreased $\mathrm{L}$ in the stomach and small intestinal contents $(P<0.05)$. Dietary supplementation with MCT did not affect $\mathrm{L}$ in the colon and rectal content or $\mathrm{C}$ in any of the contents of the intestinal tract sections.

Table 4. Effects of dietary $\mathrm{MCT}^{1}$ on microbial counts in intestinal tract

\begin{tabular}{|c|c|c|c|c|c|c|}
\hline \multirow[b]{2}{*}{ Indices } & \multicolumn{4}{|c|}{ Treatment } & \multirow[b]{2}{*}{ SEM } & \multirow[b]{2}{*}{$P$} \\
\hline & $\begin{array}{l}6.0 \% \\
\text { soya oil }\end{array}$ & $\begin{array}{l}4.8 \% \\
\text { soya oil + } \\
1.2 \% \text { MCT }\end{array}$ & $\begin{array}{l}3.0 \% \\
\text { soya oil + } \\
3.0 \% \text { MCT }\end{array}$ & $\begin{array}{l}1.2 \% \\
\text { soya oil + } \\
4.8 \% \text { MCT }\end{array}$ & & \\
\hline $\bar{n}$ & 8 & 8 & 8 & 8 & - & - \\
\hline \multicolumn{7}{|c|}{ Stomach } \\
\hline$L^{2}$ & $7.36^{\mathrm{b}}$ & $7.93^{\mathrm{b}}$ & $6.54^{a}$ & $5.99^{a}$ & 0.221 & 0.001 \\
\hline$C^{3}$ & 4.83 & 4.36 & 4.37 & 3.06 & 0.502 & 0.145 \\
\hline $\mathrm{L} / \mathrm{C}$ & 1.51 & 1.74 & 1.70 & 2.63 & 0.329 & 0.153 \\
\hline$L+C$ & $12.19^{b}$ & $11.92^{\mathrm{b}}$ & $10.91^{b}$ & $9.05^{\mathrm{a}}$ & 0.576 & 0.019 \\
\hline \multicolumn{7}{|c|}{ Small intestine } \\
\hline $\mathrm{L}^{2}$ & $7.90^{\mathrm{b}}$ & $9.23^{c}$ & $7.23^{\mathrm{ab}}$ & $7.13^{\mathrm{a}}$ & 0.218 & 0.001 \\
\hline$C^{3}$ & 6.52 & 6.18 & 5.95 & 5.94 & 0.299 & 0.514 \\
\hline $\mathrm{L} / \mathrm{C}$ & $1.24^{\mathrm{a}}$ & $1.47^{\mathrm{b}}$ & $1.22^{\mathrm{a}}$ & $1.22^{\mathrm{a}}$ & 0.033 & 0.001 \\
\hline$L+C$ & $14.42^{\mathrm{ab}}$ & $15.41^{b}$ & $13.22^{\mathrm{a}}$ & $13.07^{a}$ & 0.496 & 0.027 \\
\hline \multicolumn{7}{|l|}{ Caecum } \\
\hline $\mathrm{L}^{2}$ & $9.20^{\mathrm{bc}}$ & $10.07^{c}$ & $8.03^{a}$ & $8.45^{\mathrm{ab}}$ & 0.351 & 0.012 \\
\hline$C^{3}$ & 6.91 & 6.54 & 6.67 & 5.99 & 0.576 & 0.212 \\
\hline $\mathrm{L} / \mathrm{C}$ & $1.36^{\mathrm{ab}}$ & $1.58^{c}$ & $1.20^{\mathrm{a}}$ & $1.41^{b}$ & 0.049 & 0.003 \\
\hline$L+C$ & 16.11 & 16.53 & 14.70 & 14.44 & 0.581 & 0.079 \\
\hline \multicolumn{7}{|c|}{ Colon + rectum } \\
\hline $\mathrm{L}^{2}$ & 9.59 & 9.97 & 9.16 & 9.24 & 0.231 & 0.120 \\
\hline$C^{3}$ & 7.23 & 6.80 & 6.76 & 5.90 & 0.325 & 0.078 \\
\hline $\mathrm{L} / \mathrm{C}$ & $1.34^{\mathrm{a}}$ & $1.47^{b}$ & $1.36^{\mathrm{a}}$ & $1.58^{c}$ & 0.032 & 0.002 \\
\hline$L+C$ & 16.88 & 16.76 & 16.76 & 15.14 & 0.546 & 0.156 \\
\hline
\end{tabular}
contents of young pigs, $\log _{10} \mathrm{CFU} \cdot \mathrm{g}^{-1}$ fresh content

${ }^{1} \mathrm{MCT}$ - medium-chain triacylglycerols; ${ }^{2,3} \mathrm{~L}$ - lactic acid bacteria; $\mathrm{C}$ - coliforms; ${ }^{\mathrm{a}-\mathrm{c}}$ least-squares means within a row lacking a common superscript letter differ at $P<0.05$ 
Table 5. Effects of dietary $\mathrm{MCT}^{1}$ on apparent digestibility (\%) of medium-chain fatty acid and protein on young pigs

\begin{tabular}{|c|c|c|c|c|c|c|}
\hline \multicolumn{5}{|c|}{ Treatment } & \multirow[b]{2}{*}{ SEM } & \multirow[b]{2}{*}{$P$} \\
\hline Indices & $\begin{array}{l}6.0 \% \\
\text { soya oil }\end{array}$ & $\begin{array}{l}4.8 \% \\
\text { soya oil + } \\
1.2 \% \text { MCT }\end{array}$ & $\begin{array}{l}3.0 \% \\
\text { soya oil + } \\
3.0 \% \text { MCT }\end{array}$ & $\begin{array}{l}1.2 \% \\
\text { soya oil + } \\
4.8 \% \text { MCT }\end{array}$ & & \\
\hline C6:0 & - & $97.5^{\mathrm{a}}$ & $98.6^{\mathrm{ab}}$ & $99.2^{b}$ & 0.35 & 0.034 \\
\hline C8:0 & - & 98.1 & 98.8 & 99.3 & 0.34 & 0.120 \\
\hline C10:0 & - & 99.3 & 99.2 & 99.4 & 0.30 & 0.916 \\
\hline Protein & $78.1^{\mathrm{a}}$ & $79.2^{\mathrm{ab}}$ & $80.7^{\mathrm{bc}}$ & $81.9^{c}$ & 0.82 & 0.040 \\
\hline
\end{tabular}

${ }^{1} \mathrm{MCT}$ - medium-chain triacylglycerols; ${ }^{\mathrm{a}-\mathrm{c}}$ least-squares means within a row lacking a common superscript letter differ at $P<0.05$

Dietary supplementation with $1.2 \%$ MCT resulted in the highest L-to-C ratio in small intestinal and caecal contents $(P<0.05$; Table 4$)$. Dietary supplementation with $4.8 \%$ MCT resulted in the lowest $\mathrm{L}+\mathrm{C}$ in the stomach content and the highest L-to-C ratio in the colon and rectal content $(P<0.05)$. Dietary supplementation with $3.0 \%$ and $4.8 \%$ MCT led to lower $\mathrm{L}+\mathrm{C}$ in the small intestinal content compared with supplementation with $1.2 \% \mathrm{MCT}$ $(P<0.05)$.

The apparent digestibility (AD) of MCFA was high (> 97\%). Dietary supplementation with $4.8 \%$ MCT increased the AD of C6:0 $(P<0.05$; Table 5). Dietary supplementation with $4.8 \%$ MCT increased the AD of crude protein $(P<0.05$; Table 5$)$.

\section{Discussion}

The finding that dietary supplementation with $4.8 \% \mathrm{MCT}$ increases the feed utilization efficiency of young pigs agrees with the findings in weanling pigs (Dierick et al., 2002b; Hanczakowska et al., 2011) and in broilers (Chiang et al., 1990a) when lower levels of MCT (i.e. $0.2 \%-5 \%$ in the diet) were fed. On the other hand, researchers have found that supplementing higher levels of MCT in diets (i.e. $10 \%-20 \%$ ) did not affect the weight gain or feed utilization efficiency of young pigs (Allee et al., 1972; Newport et al., 1979) or rats (Travis et al., 1979). Furthermore, Lavau and Hashim (1978) and Baba et al. (1982) reported that dietary supplementation with $20 \%-35 \%$ MCT decreased the weight gain of rats. These results indicate that supplementation with a lower level of MCT in diets may improve the growth performance of animals. A higher level of MCT in diets (i.e. more than $5 \%-10 \%$ ) may not be beneficial, and even detrimental, to the growth performance of animals.

The metabolizable energy (ME) of MCT was determined to be $32.92 \mathrm{MJ} \cdot \mathrm{kg}^{-1}$ (Lee and Chiang,
1994), which is lower than the ME of $35.15 \mathrm{MJ} \cdot \mathrm{kg}^{-1}$ in SO (NRC, 1998). Therefore, replacing the dietary supplement SO by MCT would decrease the ME content in the diet, thus decreasing feed utilization efficiency. However, the opposite was observed in the present study and in other research (Chiang et al., 1990a; Dierick et al., 2002b). These results indicate that besides $\mathrm{ME}$, other physiological factors in MCT might be involved in improving the feed utilization efficiency in animals.

The observation that dietary supplementation with $4.8 \%$ MCT decreases $\mathrm{L}+\mathrm{C}$ in the stomach and small intestinal contents agrees with the finding of Dierick et al. (2002a,b). These authors showed that dietary MCFA could inhibit Lactobacillus, Streptococcus and Escherichia coli in the stomach and small intestine of weanling pigs. We also observed that dietary supplementation with MCT increased the L-to-C ratio, indicating a favourable shift of microbiota, in the small and large intestinal contents. The bactericidal effect of antibiotics, especially on harmful bacteria, is one of the reasons for their growth-promoting effect observed in animals (Vervaeke et al., 1979; Dierick et al., 1986a,b; Jensen, 1993; Chesson, 1994; Anderson et al., 1999).

In our study pigs digested more than $97 \%$ of ingested MCFA. According to Dierick et al. (2002b), the $\mathrm{AD}$ of $\mathrm{C} 8: 0$ and $\mathrm{C} 10: 0$ were higher than $98 \%$ in weanling pigs. After being absorbed, MCFA could be transported via the portal vein directly to the liver, entering the mitochondrial matrix for $\beta$-oxidation without using carnitine as a carrier (Bremer, 1980). MCFA could thus be used more efficiently as an energy source compared with long-chain fatty acids.

The finding that dietary supplementation with MCT improves the AD of crude protein of young pigs aligns with recent findings (Hanczakowska et al., 2011; Hong et al., 2012). Hanczakowska et al. (2011) indicated that MCT changes the structure of small intestinal mucosa, i.e. increased villus height, and may increase the $\mathrm{AD}$ of crude protein of young pigs. In addition, MCT stimulated secretion of cholecystokinin (CCK) in the small intestine in pigs (Stubbs and Stabile, 1985), rats (Douglas et al., 1990) and humans (Isaacs et al., 1987). CCK could stimulate the secretion of pancreatic proteases (i.e. trypsin, chymotrypsin and carboxypeptidase) and intestinal peptidases (i.e. aminopeptidase, dipeptidase, tripeptidase and tetrapeptidase; Tortora and Anagnostakos, 1984). Therefore, dietary MCT may stimulate the secretion of CCK and the enzymatic digestion of protein, thus improving the $\mathrm{AD}$ of crude protein in young pigs. 
The improvement of crude protein digestibility may provide more protein for deposition in pigs. It was found that dietary MCT increased body protein deposition (Chiang et al., 1990a) and decreased body fat deposition (Lavau and Hashim, 1978; Newport et al., 1979; Travis et al., 1979; Baba et al., 1982) in animals. The decreasing effect of MCT on body fat deposition may be due to the lower energy content in MCT-containing diets and a reflection of the increasing effect of MCT on protein deposition. Because about five times less energy is needed to deposit a unit of lean tissue compared with fat tissue (Van Es, 1977), dietary MCT may increase and decrease the deposition of protein and fat, respectively, and thus improve the feed utilization efficiency of pigs.

\section{Conclusions}

In conclusion, dietary supplementation with $4.8 \%$ medium-chain triacylglycerols could be used to modify intestinal microbiota and improve feed utilization efficiency in young pigs.

\section{Acknowledgements}

The authors gratefully acknowledge the financial support of the Chant Oil Company, New Taipei City, Taiwan.

\section{References}

Allee G.L., Romsos D.R., Levelle G.A., Baker D.H., 1972. Metabolic consequences of dietary medium chain triglycerides in the pig. Proc. Soc. Exp. Biol. Med. 139, 422-433

Anderson D., McCracken V., Aminov R., Simpson J., Mackie R., Verstegen M., Gaskins H., 1999. Gut microbiology and growth-promoting antibiotics in swine. Pig News Inform. 20, $115 \mathrm{~N}-122 \mathrm{~N}$

AOAC, 1984. Association of Official Analytical Chemists, Official Methods of Analysis. 14 $4^{\text {th }}$ Edition. Washington, DC

Baba N., Bracco E.F., Hashim S.A., 1982. Enhanced thermogenesis and diminished deposition of fat in response to overfeeding with diet containing medium chain triglyceride. Amer. J. Clin. Nutr. 35, 678-682

Bach A.C., Babayan V.K., 1982. Medium-chain triglycerides: an update. Amer. J. Clin. Nutr. 36, 950-962

Bremer J., 1980. Carnitine and its role in fatty acid metabolism. Trends Biochem. Sci. 2, 205-209

Chesson A., 1994. Probiotics and other intestinal mediators. In: D. Cole (Editor). Principles of Pig Science. Nottingham University Press. Loughborough, pp. 197-214

Chiang S.H., Huang K.H., Lee H.F., 1990a. Effects of medium chain triglyceride on energy metabolism, growth and body fat in broilers. J. Chin. Soc. Anim. Sci.19, 11-18

Chiang S.H., Pettigrew J.E., Clarke S.D., Cornelius S.G., 1990b. Limits of medium-chain and long-chain triacylglycerol utilization by neonatal piglets. J. Anim. Sci. 68, 1632-1638
Dierick N.A., Decuypere J.A., Molly K., Van Beek E., Vanderbeke E., 2002a. The combined use of triacylglycerols containing medium-chain fatty acids (MCFAs) and exogenous lipolytic enzymes as an alternative for nutritional antibiotics in piglet nutrition: I. In vitro screening of the release of MCFAs from selected fat sources by selected exogenous lipolytic enzymes under simulated pig gastric conditions and their effects on the gut flora of piglets. Livest. Prod. Sci. 75, 129-142

Dierick N.A., Decuypere J.A., Molly K., Van Beek E., Vanderbeke E., $2002 \mathrm{~b}$. The combined use of triacylglycerols (TAGs) containing medium chain fatty acids (MCFAs) and exogenous lipolytic enzymes as an alternative to nutritional antibiotics in piglet nutrition: II. In vivo release of MCFAs in gastric cannulated and slaughtered piglets by endogenous and exogenous lipases; effects on the luminal gut flora and growth performance. Livest. Prod. Sci. 76, 1-16

Dierick N.A., Vervaeke I.J., Decuypere J.A., Henderickx H.K., 1986a. Influence of the gut flora and of some growth-promoting feed additives in nitrogen metabolism in pigs. I. Studies in vitro. Livest. Prod. Sci. 14, 161-176

Dierick N.A., Vervaeke I.J., Decuypere J.A., Henderickx H.K., 1986 b. Influence of the gut flora of some growth-promoting feed additives in nitrogen metabolism in pigs. II. Studies in vivo. Livest. Prod. Sci. 14, 177-193

Douglas B.R., Jansen J.B., de Jong A.J., Lamers C.B., 1990. Effects of various triglycerides on plasma cholecystokinin levels in rats. J. Nutr. 120, 686-690

Furuse M., Mabayo R.T., Kita K., Okumura J., 1992. Effect of dietary medium chain triglyceride on protein and energy utilisation in growing chicks. Brit. Poultry Sci. 33, 49-57

Hanczakowska E., Szewczyk A., Okoń K., 2011. Effects of dietary caprylic and capric acids on piglet performance and mucosal epithelium structure of the ileum. J. Anim. Feed Sci. 20, $556-565$

Hong S.M., Hwang J.H., Kim I.H., 2012. Effect of medium-chain triglyceride (MCT) on growth performance, nutrient digestibility, blood characteristics in weanling pigs. Asian-Austr. J. Anim. Sci. 25, 1003-1008

Isaacs P.E., Ladas S., Forgacs I.S., Dowling R.H., Ellam S.V., Adrian T.E., Bloom S.R., 1987. Comparison of effects of ingested medium- and long-chain triglyceride on gallbladder volume and release of cholecystokinin and other gut peptides. Digest. Dis. Sci. 32, 481-486

Jensen B., 1993. The possibility of manipulating the microbial activity in the digestive tract of monogastric animals. In: Proceedings of the $44^{\text {th }}$ Annual Meeting of the European Association for Animal Production. Aarhus, p. 20

Lavau M.M., Hashim S.A., 1978. Effect of medium chain triglyceride on lipogenesis and body fat in the rat. J. Nutr. 108, 613-620

Lee H.F., Chiang S.H., 1994. Energy value of medium-chain triglycerides and their efficacy in improving survival of neonatal pigs. J. Anim. Sci. 72, 133-138

Newport M.J., Storry J.E., Tuckley B., 1979. Artificial rearing of pigs. 7. Medium chain triglycerides as a dietary source of energy and their effect on live-weight gain, feed:gain ratio, carcass composition and blood lipids. Brit. J. Nutr. 41, 85-93

Nieman C., 1954. Influence of trace amounts of fatty acids on the growth of microorganisms. Bacteriol. Rev. 18, 147-163

NRC, 1996. Guide for the Care and Use of Laboratory Animals. $7^{\text {th }}$ Edition. National Academy Press. Washington, DC

NRC, 1998. Nutrient Requirements of Swine. $10^{\text {th }}$ revised Edition. National Academy Press. Washington, DC

SAS, 2003. SAS User's Guide. Statistical Analysis Institute Inc. Cary, NC 
Stubbs R.S., Stabile B.E., 1985. Role of cholecystokinin in pancreatic exocrine response to intraluminal amino acids and fat. Amer. J. Physiol. 11, G347-G352

Sukhija P.S., Palmquist D.L., 1988. Rapid method for determination of total fatty acid content and composition of feedstuffs and feces. J. Agr. Food Chem. 36, 1202-1206

Tortora G.J., Anagnostakos N.P., 1984. Principles of Anatomy and Physiology. $4^{\text {th }}$ Edition. Harper and Row Publishers. New York

Travis D., Minenna A., Frier H., 1979. Effect of medium chain triglyceride on energy metabolism and body composition in the rat. Fed. Proc. 38, 561 (Abstr.)
Van Es A.J.H., 1977. The energetic of fat deposition during growth. J. Nutr. Metab. 21, 88-95

Vervaeke I.J., Decuypere J.A., Dierick N.A., Henderickx H.K., 1979. Quantitative in vitro evaluation of the energy metabolism influenced by Virginiamycin and Spiramycin used as growth promoters in pig nutrition. J. Anim. Sci. 49, 846-856

Williams C.H., David D.J., lismaa O., 1962. The determination of chromic oxide in faeces samples by atomic absorption spectrophotometry. J. Agr. Sci. 59, 381-385 